\title{
Prevalence of HIV among general surgical patients in southeastern Nigeria
}

\author{
Stanley Anyanwu*, Gabriel Chianakwana, Eric Ihekwoaba \\ From $12^{\text {th }}$ International Conference on Malignancies in AIDS and Other Acquired Immunodeficiencies \\ (ICMAOI) \\ Bethesda, MD, USA. 26-27 April, 2010
}

\section{Background}

With the advent of HAART, many HIV patients are now living longer. It is expected that the incidence of HIV-related malignancies will increase, with additional burden of operating on HIV patients in areas of chronic severe shortages where minimum basic precautions may not always be feasible. We decided to assess the HIV prevalence in surgical patients and compare the periods 2001-04 and 2008-09.

\section{Aim}

To determine HIV seropositivity among elective general surgical patients at Nnamdi Azikiwe University Teaching Hospital, Nnewi.

\section{Patients and methods}

All surgical patients were sent for HIV screening as part of their workup for surgery. Patients testing positive were sent for further confirmatory tests.

\section{Results}

During the period 2008/09, 75 out of 2350 (3.25\%) patients tested were positive for HIV. This compares with 78 out 2208 in the 3 -year period 2001-04.(3.5\%). Of this number, only $30.4 \%$ of these seropositive patients are receiving antiretroviral treatment. Males were affected more than the females and the reproductive age group [30-40] was the most affected.

\section{Conclusion}

The prevalence of HIV seropositivity among general surgical patients has remained the same over the past 10 years.

*Correspondence: sncanyanwu@yahoo.com

Department of Surgery, Nnamdi Azikiwe University Teaching Hospital, Nnewi, Anambra State, Nigeria
The prevalence of $3-3.5 \%$ is significantly lower than the figures quoted from sentinel studies in Nigeria.

\section{Acknowledgements}

This article has been published as part of Infectious Agents and Cancer Volume 5 Supplement 1, 2010: Proceedings of the $12^{\text {th }}$ International Conference on Malignancies in AIDS and Other Acquired Immunodeficiencies (ICMAOI). The full contents of the supplement are available online at http://www.biomedcentral.com/1750-9378/5?issue=S1.

Published: 11 October 2010

doi:10.1186/1750-9378-5-S1-A64

Cite this article as: Anyanwu et al:: Prevalence of HIV among general surgical patients in southeastern Nigeria. Infectious Agents and Cancer 2010 5(Suppl 1):A64.
Submit your next manuscript to BioMed Central and take full advantage of:

- Convenient online submission

- Thorough peer review

- No space constraints or color figure charges

- Immediate publication on acceptance

- Inclusion in PubMed, CAS, Scopus and Google Scholar

- Research which is freely available for redistribution

Submit your manuscript at www.biomedcentral.com/submit
C Biomed Central 